\title{
GROWTH RATE AND NUTRITIONAL STATUS OF AN ORGANIC COFFEE CROPPING SYSTEM
}

\author{
Marta dos Santos Freire Ricci ${ }^{1 *}$; Bruno José Rodrigues Alves ${ }^{1}$; Simone Cordeiro de Miranda ${ }^{1}$; \\ Fabio Freire de Oliveira² \\ ${ }^{1}$ Embrapa Agrobiologia, C.P. 74505 - 23851-970 - Seropédica, RJ - Brasil. \\ ${ }^{2}$ UFRuralRJ - Depto. de Solos, C.P. 74511 - BR 465, km 47 - 23851-970 - Seropédica, RJ - Brasil. \\ *Corresponding author <marta@cnpab.embrapa.br>
}

\begin{abstract}
In view of the low $\mathrm{N}$ concentration in organic fertilizers, it is necessary to use high rates of such fertilizers to attend coffee crop requirements. Hence, $\mathrm{N}$ is the most limiting nutrient for organic coffee production. The objective of this work was to evaluate the influence of sunn hemp (Crotalaria juncea) organic fertilization on the growth and nutritional status of coffee cultivars, as well as to quantify plant biomass and $\mathrm{N}$ input derived from biological nitrogen fixation, and their effect on soil chemical characteristics. The experiment consisted of six coffee (Coffea arabica) cultivars intercropped with and without sunn hemp sown in November 2001 and pruned at mid-height 76 days later. At 175 days, the standing biomass of the legume was cut, measuring dry mass, total $\mathrm{N}, \mathrm{P}, \mathrm{K}, \mathrm{Ca}, \mathrm{Mg}$, and ${ }^{15} \mathrm{~N}$ natural abundance, resulting $16 \mathrm{tha}^{-1}$ of dry mass and the recycling of 444, 21, 241, 191, and $44 \mathrm{~kg} \mathrm{ha}^{-1}$ of N, P, K, Ca, and Mg, respectively. Cultivars 'Obatã' and 'Catuaí Vermelho' presented the highest growth rates in terms of plant height, while cultivars 'Icatu' and 'Oeiras' presented the lowest rates. Biological nitrogen fixation associated to the legume introduced more than $200 \mathrm{~kg} \mathrm{ha}^{-1}$ of $\mathrm{N}$, which is a demonstration that $\mathrm{N}$ fertilization in organic cropping systems is a valuable alternative. Intercropping lead to a constant coffee leaf $\mathrm{N}$ content during the entire cropping cycle, contrary to what was observed in plots grown without sunn hemp.
\end{abstract}

Key words: Coffea arabica, Crotalaria juncea, biological nitrogen fixation, nutrient input, green manure

\section{TAXA DE CRESCIMENTO E ESTADO NUTRICIONAL DO CAFEEIRO EM SISTEMA DE PRODUÇÃO ORGÂNICO}

\begin{abstract}
RESUMO: Devido a baixa concentração de N nos fertilizantes orgânicos, são necessárias doses elevadas dessas fontes para suprir as exigências do cafeeiro. Por esta razão, o N é o nutriente mais limitante na cafeicultura orgânica. O objetivo do trabalho foi avaliar, em sistema orgânico de produção, a influência da Crotalaria juncea no crescimento e estado nutricional de cultivares de café, bem como quantificar o aporte de biomassa vegetal e de $\mathrm{N}$ via fixação biológica, além do efeito sobre as características químicas do solo. O experimento foi constituído por seis cultivares de café (Coffea arabica), cultivadas com e sem Crotalaria juncea. A crotalária foi semeada em novembro de 2001, e aos 76 dias foi podada a meia altura. Aos 175 dias, foi cortada e quantificada a biomassa vegetal, os teores de $\mathrm{N}, \mathrm{P}, \mathrm{K}, \mathrm{Ca}, \mathrm{Mg}$ e a abundância natural de ${ }^{15} \mathrm{~N}$. O cultivo da crotalária proporcionou o aporte de $16 \mathrm{t} \mathrm{ha}^{-1}$ de matéria seca e a reciclagem de 444, 21, 241, 191 e $44 \mathrm{~kg} \mathrm{ha}^{-1} \mathrm{de}$ $\mathrm{N}, \mathrm{P}, \mathrm{K}, \mathrm{Ca}$ e Mg, respectivamente. Os cultivares ‘Obatã' e ‘Catuaí Vermelho’ apresentaram as maiores taxas de crescimento em altura, enquanto os cultivares 'Icatu' e 'Oeiras', as menores taxas. A fixação biológica de $\mathrm{N}$ proporcionou um aporte de $\mathrm{N}$ superior a $200 \mathrm{~kg} \mathrm{ha}^{-1}$ de $\mathrm{N}$, demonstrando ser uma alternativa para o produtor fertilizar os sistemas orgânicos com $\mathrm{N}$. O cultivo da crotalária permitiu que o teor de $\mathrm{N}$ acumulado no tecido foliar dos cafeeiros se mantivesse igual após um ciclo da cultura, ao contrário do que foi observado nas parcelas não cultivadas com a leguminosa.

Palavras-chave: Coffea arabica, Crotalaria juncea, fixação biológica de nitrogênio, aporte de nutrientes, adubação verde
\end{abstract}

\section{INTRODUCTION}

Organic coffee cropping is made using only manures, composts, green manures, ash, thermophosphates, and bone meal, among others. A physically well-structured soil, with medium to high organic matter and nutrient contents, and good biological activity, may represent the key factor for an equilibrium of agroecosystems, and consequently for the health of the plants. For coffee, nitrogen $(\mathrm{N})$ content is considered suitable between 26 and $30 \mathrm{~g} \mathrm{~kg}^{-1}$ of dry matter (Ribeiro et al., 1999). For this reason, this nutrient is considered the most limiting in organic coffee cropping, since its low concentration in organic fertilizers demands the application of high rates to supply the amount of $\mathrm{N}$ required by the plant. 
One of the alternatives for the producer to increase the supply of $\mathrm{N}$ to coffee plants is green fertilization, which consists in growing plants with the objective of incorporating them or leaving them on soil surface in order to preserve or even increase soil fertility (Calegari et al., 1993; Costa et al., 2003). Species of the family Leguminosae are the most used in green fertilization. Because of their capacity to fix atmospheric $\mathrm{N}_{2}$, they can add more than $150 \mathrm{~kg} \mathrm{ha}^{-1}$ year ${ }^{-1}$ of $\mathrm{N}$ to soils (Franco \& Souto, 1984). For this reason, the plant biomass produced by legumes constitutes an important alternative to recycle nutrients and to introduce organic matter and $\mathrm{N}$ into the system, making the producer less dependent of the use of manures or composts as organic sources of $\mathrm{N}$.

The introduction of plant biomass into the system, in addition to acting directly on the preservation of soil fertility, produces organic acids that increase the solubilization of minerals, and also mediates nutrient cycling in deeper soil layers, making them available for plant species with shallow root systems (Fundação Cargill, 1984; Muñoz, 1997; Khatounian, 2002).

In addition to benefits on soil chemical properties as a result of the introduction of plant biomass, the effects on soil physical and biological properties are also worth mentioning. The presence of vegetation covering the soil reduces the impact of rain and avoids soil disaggregation and later erosion. Plant biomass increases soil infiltration rate and water retention capacity, soil porosity and aeration, and attenuates temperature oscillations, intensifying biological activity (Espíndola et al., 1997; ANACAFÉ, 1999; Chaves, 2001).

In organic coffee cropping, the legumes employed for green fertilization can be used prior to coffee cultivation or grown between coffee rows starting when the crop is implemented (Pavan \& Chaves, 1998; Chaves, 1999); care should be taken only to select species that are not aggressive and will not compete for water and nutrients (Guimarães et al., 2002; Ricci et al., 2002).

The objective of this work was to evaluate, in an organic coffee production system, the influence of green manure with Crotalaria juncea grown in plots between coffee rows on the growth and nutritional status of coffee cultivars, as well as to quantify the input of plant biomass and $\mathrm{N}$ via biological fixation, and their effect on soil chemical characteristics.

\section{MATERIAL AND METHODS}

The experiment started in December 2000, in an area previously cultivated with Napier grass, located in Valença, RJ, Brazil at $22^{\circ} 20 \mathrm{~S}$ and $43^{\circ} 43^{\prime} \mathrm{W}$. The total area of 1.5 ha has a predominantly leveled topography, with slopes smaller than 5\%. Elevation is approximately $608 \mathrm{~m}$, with a mean annual precipitation of $1,280 \mathrm{~mm}$ and a mean annual temperature of $25.5^{\circ} \mathrm{C}$. The climate in the region is classified as Cwa, according to Köppen’s classification.

The soil was classified as an Ultisol, and characterized according to a methodology used by EMBRAPA (1979), showing the following chemical characteristics: $\mathrm{pH}=5.3$ (in water); $\mathrm{Al}^{+3}=1 \mathrm{mmol} \mathrm{dm}^{-3} ; \mathrm{Ca}^{+2}=18 \mathrm{mmol}$ $\mathrm{dm}^{-3} ; \mathrm{Mg}^{+2}=7 \mathrm{mmol}_{\mathrm{c}} \mathrm{dm}^{-3}$; exchangeable $\mathrm{P}=2.0 \mathrm{mg} \mathrm{dm}^{-5}$ (Mehlich 1); $\mathrm{K}^{+}=128 \mathrm{mg} \mathrm{dm}^{-3}$; organic $\mathrm{C}=13.5 \mathrm{~g} \mathrm{~kg}^{-1}$ (Walkley-Black); base saturation $=56 \%$.

The area was plowed, harrowed, and the acidity was corrected with dolomitic lime; $500 \mathrm{~kg} \mathrm{ha}^{-1}$ in order to achieve a base saturation of $60 \%$. The rate to be applied was calculated using the Base Saturation method (Alvarez \& Ribeiro, 1999). The experiment consisted of six coffee cultivars (Coffea arabica), with or without Crotalaria juncea as an intercrop. Cultivars used were: Catuaí Vermelho IAC 144 (tall), non resistant to rust; Tupi IAC 1669/33 (short); Oeiras MG 6851 (short); Icatu Amarelo IAC 2944 (tall); Catucaí Amarelo 2 SL (tall), and Obatã IAC 1669-20 (short), which are rust-resistant. The cultivars were planted in plots $(27 \mathrm{~m} \times 10 \mathrm{~m})$ and the green manure in subplots $(13.5 \mathrm{~m} \times 10 \mathrm{~m})$ between coffee rows arranged in a randomized block design with eight replicates. The plots consisted of four coffee rows planted at a $2.5 \mathrm{~m} \times 0.7 \mathrm{~m}$ spacing.

The seedlings, grown in plastic bags, were planted in February 2001 using a substrate consisted of loam, sand, and compost at a 1:1:1 proportion, enriched with $10 \%$ rock phosphate. Pit fertilization at transplanting was calculated based on the mean $\mathrm{N}$ content of cattle manure, which is $1.7 \% \mathrm{~N}$ (De-Polli, 1988), and on manure dry weight; $2.5 \mathrm{~kg}$ cattle manure were applied, with addition of $300 \mathrm{~g}$ of a (1:1) mixture of magnesium thermophosphate $\left(18 \% \mathrm{P}_{2} \mathrm{O}_{5} ; 20 \% \mathrm{Ca} ; 7.0 \% \mathrm{Mg}\right)+$ wood ash $(5$ to $7 \% \mathrm{~K})$. A sidedressing fertilization was performed 40 days later with $250 \mathrm{~g}$ 'poultry litter' manure per plant (mean N content of 2.7\%, according to De-Polli, 1988). A spray with biofertilizer enriched with micronutrients (Fernandes, n.d.), at a concentration of $4 \%$, was performed as nutritional supplementation and preventive control of coffee pests and diseases. The annual maintenance fertilization was calculated based on the $\mathrm{N}$ content in the 'poultry litter' manure $(2.7 \% \mathrm{~N})$, considering its dry weight, and the total rate was split in two $250 \mathrm{~g}$ applications per plant, as sidedressing, in October 2001 and March 2002, respectively. One hundred graus of magnesium thermophosphate we3re applied per plant as a source of $\mathrm{P}, \mathrm{Ca}$, and $\mathrm{Mg}$.

The green manure was planted by mid November, 2001; three $C$. juncea rows were sown at distances of $0.5 \mathrm{~m}, 1.0 \mathrm{~m}$, and $1.5 \mathrm{~m}$ from the coffee row, respectively. Seeds were inoculated with Bradyrhizobium sp. (BR 2001 and BR 2003 strains); 250 grams of the inoculant were applied for each $10 \mathrm{~kg}$ of sunn hemp seeds. At 76 days after planting (d.a.p.), the sunn hemp reached a 
$2.0 \mathrm{~m}$ height and was pruned at mid-height. The shoot biomass part was estimated in a $0.5 \mathrm{~m}^{2}$ area. All material contained in this area was collected and the green mass was quantified. In order to calculate total dry matter, subsamples were collected, weighed, dried in an oven at $65^{\circ} \mathrm{C}$, and used for $\mathrm{N}, \mathrm{P}, \mathrm{K}, \mathrm{Ca}$, and $\mathrm{Mg}$ content analysis. $\mathrm{N}$ content determination was performed by sulfuric acid digestion and distillation (Alves et al., 1999); P, K, Ca, and $\mathrm{Mg}$ by nitric-perchloric acid digestion (Bataglia et al, 1983), and $P$ in a spectrophotometer in the visible range, from the formation of blue color of the phosphatemolybdate complex in the presence of ascorbic acid as a reducer (EMBRAPA, 1979). Sunn hemp was submitted to a final cut on 04/30/02, 175 days after planting. Plant biomass was estimated using the same methodology employed at pruning.

Seedling growth was evaluated by means of height and diameter of the coffee cultivars, determined at eight months of age, which coincided with the onset of the rainy period and before sunn hemp planting. Evaluations were also performed 15 months after the planting, 26 days after sunn hemp cutting, and at the end of the rainy season. Data were collected in ten plants selected at random within the usable area in the subplots. Based on these data, the growth rate was calculated through the height and diameter using the following expression: Growth rate $=$ (final value - initial value) $\times 100 /$ initial value.

Coffee leaf samples were collected for N, P, K, $\mathrm{Ca}$, and $\mathrm{Mg}$ content analysis; compound samples were obtained for each subplot, consisting of 50 leaves removed from the third or fourth leaf pairs, starting at the end of the branches in the upper third of the plant (Malavolta et al., 1989). A third leaf sampling was carried out 162 days after cutting the sunn hemp, in October 2002, in order to analyze N, P, K, Ca, and Mg contents, following the same methodologies previously cited. During the same period, soil samples consisting of six subsamples were also taken from each subplot, collected at a depth between 0 and $20 \mathrm{~cm}$, and analyzed according to EMBRAPA (1979).

The BNF contribution by sunn hemp was estimated by the delta $15 \mathrm{~N}$ technique (Shearer \& Khol, 1986), using legume plant samples taken at 173 d.a.p. At the time, spontaneous non-legume species were also collected in the plots to be used as a reference of the natural abundance of ${ }^{15} \mathrm{~N}$ in the soil. In order to quantity BNF, a mean value of $\mathrm{B}$ (correction of the isotopic discrimination of ${ }^{15} \mathrm{~N}$ due to BNF - see Shearer \& Khol, 1986) equal to -1.00 was used in the calculation, based on Boddey et al. (2000). The legume and reference plants samples were finely ground for natural ${ }^{15} \mathrm{~N}$ abundance analysis, using an isotope ratio mass spectrometer (Finnigan DeltaPlus, attached to a CN Carlo Erba EA 1108 analyzer - Finnigan MAT, Bremen, Germany).

\section{RESULTS AND DISCUSSION}

Before sunn hemp cultivation, all coffee cultivars presented $\mathrm{N}$ contents above the critical level (CL); the highest value was observed for the cultivar 'Oeiras', which was prominent in relation to cultivars 'Catucaí', 'Tupi' and 'Icatu' (Table 1). Cultivars 'Obatã' and 'Catuaí Vermelho' had intermediate values in relation to the other, with regard to $\mathrm{N}$ content in the leaves (Table 1). The accumulated $\mathrm{P}, \mathrm{K}$, and Ca contents were above the critical levels established for each nutrient. However, Mg accumulation was below CL, and provided Ca:Mg ratio values above the range considered as ideal (3 to 4:1).

Sunn hemp cropping provided an input of 16 $\mathrm{t} \mathrm{ha}^{-1}$ dry matter and the cycling of 444, 21, 241, 191, and $44 \mathrm{~kg} \mathrm{ha}^{-1} \mathrm{~N}, \mathrm{P}, \mathrm{K}, \mathrm{Ca}$, and Mg, respectively, considering both pruning and final cut, performed at 76 and 175 d.a.p. (Table 2).

Table 1 - Mean N, P, K, Ca, and Mg contents present in coffee cultivar leaves, collected in November 2001, before Crotalaria juncea cultivation. Valença, RJ, Brazil.

\begin{tabular}{|c|c|c|c|c|c|}
\hline Cultivar & $\mathrm{N}$ & $\mathrm{P}$ & $\mathrm{K}$ & $\mathrm{Ca}$ & $\mathrm{Mg}$ \\
\hline & - & - & $\mathrm{g} \mathrm{kg}^{-1}-$ & - & - \\
\hline Catucaí & $30.93 \mathrm{~B}$ & $1.085 \mathrm{~A}$ & $20.1 \mathrm{~A}$ & $15.6 \mathrm{~A}$ & $3.10 \mathrm{~A}$ \\
\hline Oeiras & $33.53 \mathrm{~A}$ & $1.195 \mathrm{~A}$ & $20.4 \mathrm{~A}$ & $15.4 \mathrm{~A}$ & $3.24 \mathrm{~A}$ \\
\hline Tupi & $30.77 \mathrm{~B}$ & $1.136 \mathrm{~A}$ & $21.7 \mathrm{~A}$ & $19.3 \mathrm{~A}$ & $3.13 \mathrm{~A}$ \\
\hline Icatu & $30.65 \mathrm{~B}$ & $1.251 \mathrm{~A}$ & $18.9 \mathrm{~A}$ & $15.3 \mathrm{~A}$ & $3.17 \mathrm{~A}$ \\
\hline Obatã & $31.70 \mathrm{AB}$ & $1.371 \mathrm{~A}$ & $17.7 \mathrm{~A}$ & $14.6 \mathrm{~A}$ & $2.99 \mathrm{~A}$ \\
\hline Catuaí Vermelho & $32.64 \mathrm{AB}$ & $1.298 \mathrm{~A}$ & $17.2 \mathrm{~A}$ & $15.4 \mathrm{~A}$ & $2.99 \mathrm{~A}$ \\
\hline Mean & 31.70 & 1.223 & 19.3 & 15.9 & 3.10 \\
\hline Critical Level & 30 & $0.8-1.0$ & 18.0 & 10.0 & 3.5 \\
\hline C.V. (\%) & 5.4 & 22.7 & 22.6 & 22.3 & 14.0 \\
\hline
\end{tabular}

${ }^{1 /}$ Means followed by the same letter are not different by Tukey test at $5 \%$. 
In plots where sunn hemp was grown together with coffee, a reduction in $\mathrm{N}$ content in the leaves occurred to levels lower than the CL (Table 3). This result is possibly due to competition exercised by the legume in relation to soil available $\mathrm{N}$ during its development. Another possibility that could explain this result is the greater growth of cultivars that occurred in the presence of the green manure, thus promoting a dilution effect of $\mathrm{N}$ in the aerial part (Table 4).
Despite the greater competition exercised by the sunn hemp for soil $\mathrm{N}$, the biological nitrogen fixation contribution (BNF) provided by this legume, as evaluated by the natural ${ }^{15} \mathrm{~N}$ abundance analysis, ranged from 39 to $54 \%$ of plant accumulated N. Although the BNF percentages were low for the species (Neves et al., 2002), the large amount of $\mathrm{N}$ accumulated by the sunn hemp resulted in mean $\mathrm{N}$ input derived from BNF to the system higher than $200 \mathrm{~kg} \mathrm{ha}^{-1}$ of N. Considering that coffee plants re-

Table 2 - Mean fresh and dry plant biomass values of Crotalaria juncea and N, P, K, Ca, and Mg input, provided by pruning (January 2002) and by the final cut of the legume (April 2002). Valença, RJ, Brazil.

\begin{tabular}{|c|c|c|c|c|c|c|c|}
\hline \multirow[t]{2}{*}{$\begin{array}{l}\text { Sunn hemp } \\
\text { management }\end{array}$} & \multicolumn{2}{|c|}{ Plant Biom } & \multirow[t]{2}{*}{$\mathrm{N}$} & \multirow{2}{*}{$P$} & \multirow{2}{*}{$\mathrm{K}$} & \multirow{2}{*}{$\mathrm{Ca}$} & \multirow{2}{*}{$\mathrm{Mg}$} \\
\hline & Fresh Matter & Dry Matter & & & & & \\
\hline & \multicolumn{2}{|c|}{ - } & $-\cdots$ & --- & g ha & $-\cdots-$ & $-\cdots$ \\
\hline Pruning (76 days) & 29.0 & 6.1 & 265 & 11 & 74 & 117 & 30 \\
\hline Cut (175 days) & 30.1 & 9.9 & 179 & 10 & 167 & 74 & 14 \\
\hline Total & 59.1 & 16 & 444 & 21 & 241 & 191 & 44 \\
\hline
\end{tabular}

Table 3 - Mean N, P, K, Ca, and Mg contents in coffee cultivar leaves, 26 days (January 2002) after pruning Crotalaria juncea. Valença, RJ, Brazil.

\begin{tabular}{|c|c|c|c|c|c|c|}
\hline \multicolumn{2}{|c|}{ Treatment $^{1 /}$} & \multirow{2}{*}{$\mathrm{N}$} & \multirow{2}{*}{$\mathrm{P}$} & \multirow{2}{*}{$\mathrm{K}$} & \multirow{2}{*}{$\mathrm{Ca}$} & \multirow{2}{*}{$\mathrm{Mg}$} \\
\hline Cultivar & Green Manure & & & & & \\
\hline & & - - & 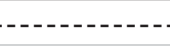 & $-\mathrm{g} \mathrm{kg}^{-1}$ & - & 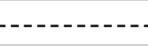 \\
\hline Catucaí & --- & $29.50 \mathrm{~A}$ & $1.607 \mathrm{AB}$ & $15.35 \mathrm{~A}$ & $12.78 \mathrm{~A}$ & $4.15 \mathrm{~A}$ \\
\hline Oeiras & --- & $29.31 \mathrm{~A}$ & $1.457 \mathrm{BC}$ & $15.20 \mathrm{~A}$ & $12.63 \mathrm{~A}$ & $4.04 \mathrm{~A}$ \\
\hline Tupi & --- & $28.85 \mathrm{~A}$ & $1.361 \mathrm{C}$ & $14.65 \mathrm{~A}$ & $11.69 \mathrm{~A}$ & $3.62 \mathrm{~A}$ \\
\hline Icatu & --- & $28.48 \mathrm{~A}$ & $1.411 \mathrm{BC}$ & $15.32 \mathrm{~A}$ & $12.73 \mathrm{~A}$ & $4.23 \mathrm{~A}$ \\
\hline Obatã & --- & $31.59 \mathrm{~A}$ & $1.413 \mathrm{BC}$ & $16.65 \mathrm{~A}$ & $12.36 \mathrm{~A}$ & $3.95 \mathrm{~A}$ \\
\hline Catuaí Vermelho & --- & $29.90 \mathrm{~A}$ & $1.817 \mathrm{~A}$ & $14.69 \mathrm{~A}$ & $12.94 \mathrm{~A}$ & $4.02 \mathrm{~A}$ \\
\hline \multirow[t]{2}{*}{ Mean for all cultivars } & With & $28.38 \mathrm{~b}$ & $1.449 \mathrm{a}$ & $15.50 \mathrm{a}$ & $12.30 \mathrm{a}$ & $3.99 \mathrm{a}$ \\
\hline & Without & $30.83 \mathrm{a}$ & $1.573 \mathrm{a}$ & $15.12 \mathrm{a}$ & $12.75 \mathrm{a}$ & $4.02 \mathrm{a}$ \\
\hline C.V. $(\%)$ & & 11.0 & 20.2 & 13.0 & 11.0 & 10.5 \\
\hline
\end{tabular}

${ }^{1 /}$ Means followed by different upper case (cultivar) and lower case letters (green manure) are different by Tukey test at 5\%.

Table 4 - Height and diameter of coffee cultivars after green manure cropping and corresponding growth rates, evaluated in the period October 2001 to May 2002. Valença, RJ, Brazil.

\begin{tabular}{|c|c|c|c|c|c|}
\hline \multicolumn{2}{|c|}{ Treatment $^{1 /}$} & \multirow{2}{*}{ Height } & \multirow{2}{*}{ Diameter } & \multicolumn{2}{|c|}{ Growth rate $2 /$} \\
\hline Cultivar & Green Manure & & & Height & Diameter \\
\hline Catucaí & --- & $71.9 \mathrm{~B}$ & $57.2 \mathrm{~B}$ & $101.2 \mathrm{~B}$ & $88.8 \mathrm{AB}$ \\
\hline Oeiras & --- & $66.1 \mathrm{C}$ & $57.5 \mathrm{~B}$ & $89.9 \mathrm{C}$ & 86.7 AB \\
\hline Tupi & --- & $59.3 \mathrm{D}$ & $50.2 \mathrm{C}$ & $100.3 \mathrm{~B}$ & $54.9 \mathrm{C}$ \\
\hline Icatu & --- & $81.8 \mathrm{~A}$ & $64.8 \mathrm{~A}$ & $66.3 \mathrm{D}$ & $74.7 \mathrm{BC}$ \\
\hline Obatã & --- & $61.1 \mathrm{CD}$ & $50.0 \mathrm{C}$ & $119.8 \mathrm{~A}$ & $51.5 \mathrm{C}$ \\
\hline Catuaí Vermelho & --- & $72.8 \mathrm{~B}$ & $62.9 \mathrm{~A}$ & $108.6 \mathrm{AB}$ & $116.1 \mathrm{~A}$ \\
\hline \multirow[t]{2}{*}{ Mean for all cultivars } & With & $70.1 \mathrm{a}$ & $57.8 \mathrm{a}$ & --- & --- \\
\hline & Without & $67.5 \mathrm{~b}$ & $56.4 \mathrm{a}$ & --- & --- \\
\hline C.V. $(\%)$ & & 11.6 & 10.0 & 10.0 & 9.6 \\
\hline
\end{tabular}

${ }^{1 /}$ Means followed by different upper case (cultivar) and lower case letters (green manure) are different by Tukey test at $5 \%$ probability.

${ }^{2 /}$ Growth rate $=($ final value - initial value $) \times 100 /$ initial value. 
quire $\mathrm{N}$ rate applications that vary between 175 and 300 $\mathrm{kg} \mathrm{ha}^{-1}$ year $^{-1}$ to attain the CL established for this nutrient (Ribeiro et al., 1999), the fixed-N here measured can be considered expressive when considering organic production systems. On the other hand, P, K, Ca, and Mg leaf contents evaluated 26 days after cutting for coffee plants grown under sunn hemp intercropping, were not different from the contents observed in the absence of the legume. The $\mathrm{P}, \mathrm{Ca}$, and $\mathrm{Mg}$ contents after cutting the sunn hemp remained above the CL (Table 3), demonstrating that cultivation of the legume was not detrimental to the coffee crop with respect to accumulation of these nutrients.

Regarding the nutrient contents accumulated in the leaf tissue of cultivars (Table 3), differences were verified only for $\mathrm{P}$ content, and cultivar 'Catuaí Vermelho' showing the highest accumulation of this nutrient. Such difference suggests that this cultivar could be more efficient in absorbing P. Even though a study cited by Saggin Jr. \& Siqueira (1996), conducted with 32 coffee cultivars, did not present differences in colonization by mycorrhizal fungi. A detailed study should be carried out based on these results to verify potential colonizations of these cultivars by mycorrhizal fungi.

The height and diameter differences presented by the cultivars were compatible with their genetic traits (Table 4). However, the cultivars that had the greatest growth rates in height, during the period between October 2001 and May 2002 were 'Obatã' and 'Catuaí Vermelho', while cultivars 'Icatu' and 'Oeiras' presented the lowest rates. With regard to plant diameter, cultivars 'Catuaí Vermelho', 'Catucaí' and 'Oeiras' had the greatest growth rates, while cultivars 'Tupi' and 'Obatã' the lowest.

$\mathrm{N}$ fluctuation at the three evaluated times (November 2001, May 2002, and October 2002) can be observed in Table 5. After 162 days counted from sunn hemp cutting, the accumulated $\mathrm{N}$ content in coffee leaf tissue was higher for the situation in which where sunn hemp was grown, a different resulting in relation to that observed 26 days after cutting the legume (Table 5). The decomposition of $C$. juncea residues is relatively quick, as reported by Resende (2000), who recorded a half-life of approximately 45 days for this species. Based on this fact, it is possible that 26 days after cutting the sunn hemp, a substantial part of the $\mathrm{N}$ present in its biomass had already been released; however, it was then temporarily immobilized by soil microorganisms, and later made again available to plants. This hypothesis could explain the rapid change that occurred in the $\mathrm{N}$ content present in coffee leaf tissue, between May and October 2002.

Although sunn hemp cultivation did not provide an increase in leaf $\mathrm{N}$ content, the data presented in Table 5 demonstrate that after one cropping cycle, the $\mathrm{N}$ content remained equal to the initial value found in the cultivars before growing the legume. The opposite was observed in subplots without sunn hemp, where $\mathrm{N}$ content decreased between the first and the last periods. This fact demonstrates that the introduction of sunn hemp between coffee rows allows for an increase in $\mathrm{N}$ availability to plants in organic systems.

With regard to nutrients $\mathrm{P}, \mathrm{K}$, and $\mathrm{Ca}$, leaf determinations made 162 days after cutting sunn hemp did not present differences in contents accumulated by the cultivars when grown with or without the legume. The Mg content in the leaf tissue was higher after sunn hemp cultivation $\left(4.24 \mathrm{~g} \mathrm{~kg}^{-1}\right)$ in relation to the content observed in coffee plants grown in the absence $\left(3.86 \mathrm{~g} \mathrm{~kg}^{-1}\right)$, and even increased in relation to the initial content evaluated before sunn hemp $\left(3.14 \mathrm{~g} \mathrm{~kg}^{-1}\right.$; Table 5).

Observing soil analyses performed before planting sunn hemp, in November 2001, it can be concluded that growing this legume did not significantly change soil

Table 5 - Mean N, P, K, Ca, and Mg contents in coffee leaves in relation to the presence of Crotalaria juncea and of evaluation seasons. Valença, RJ, Brazil, 2002.

\begin{tabular}{|c|c|c|c|c|c|c|}
\hline \multicolumn{2}{|c|}{ Treatment $^{1 /}$} & \multirow{2}{*}{$\mathrm{N}$} & \multirow{2}{*}{$\mathrm{P}$} & \multirow{2}{*}{ K } & \multirow{2}{*}{$\mathrm{Ca}$} & \multirow{2}{*}{$\mathrm{Mg}$} \\
\hline Green Manure & Season & & & & & \\
\hline & & 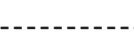 & - & $-\mathrm{g} \mathrm{kg}^{-1}$ & - & 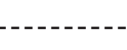 \\
\hline With & Nov/01 & $31.70 \mathrm{~A}$ & $1.22 \mathrm{~A}$ & $19.5 \mathrm{~A}$ & $16.10 \mathrm{~A}$ & $3.14 \mathrm{C}$ \\
\hline With & May/02 & $28.80 \mathrm{C}$ & $1.45 \mathrm{~A}$ & $15.5 \mathrm{~A}$ & $12.30 \mathrm{~A}$ & $3.99 \mathrm{~B}$ \\
\hline With & Oct $/ 02$ & $31.98 \mathrm{~A}$ & $1.73 \mathrm{~A}$ & $15.8 \mathrm{~A}$ & $14.22 \mathrm{~A}$ & $4.24 \mathrm{~A}$ \\
\hline Without & Nov/01 & $31.70 \mathrm{~A}$ & $1.22 \mathrm{~A}$ & $19.5 \mathrm{~A}$ & $16.10 \mathrm{~A}$ & $3.14 \mathrm{C}$ \\
\hline Without & May/02 & $30.47 \mathrm{~B}$ & $1.57 \mathrm{~A}$ & $15.1 \mathrm{~A}$ & $12.75 \mathrm{~A}$ & $4.02 \mathrm{~B}$ \\
\hline Without & Oct $/ 02$ & $29.14 \mathrm{C}$ & $1.78 \mathrm{~A}$ & $17.3 \mathrm{~A}$ & $14.31 \mathrm{~A}$ & $3.96 \mathrm{~B}$ \\
\hline C.V. (\%) & & 9.0 & 20.1 & 19.4 & 17.8 & 12.2 \\
\hline
\end{tabular}

${ }^{1 /}$ Means followed by the same letter are not different by Tukey test at $5 \%$. 
Table 6 - Mean soil pH, Al, Ca, Mg, P, K, and organic carbon analyzed 162 days (October 2002) after cutting Crotalaria juncea. Valença, RJ, Brazil.

\begin{tabular}{|c|c|c|c|c|c|c|c|c|}
\hline \multicolumn{2}{|c|}{ Treatment $^{1 /}$} & \multirow{2}{*}{$\mathrm{pH}$} & \multirow{2}{*}{$\mathrm{Al}$} & \multirow{2}{*}{$\mathrm{Ca}$} & \multirow{2}{*}{$\mathrm{Mg}$} & \multirow{2}{*}{$\mathrm{P}$} & \multirow{2}{*}{ K } & \multirow{2}{*}{ O.C. } \\
\hline Cultivar & Green Manure & & & & & & & \\
\hline & & $\mathrm{H}_{2} \mathrm{O}$ & ----- cmo & $\mathrm{dm}^{-3}----$ & ---.--- & $m g \mathrm{dm}^{-3}-$ & $\begin{array}{l}-\cdots--- \\
-\cdots\end{array}$ & $\%$ \\
\hline Catucaí & --- & $5.14 \mathrm{~A}$ & $0.10 \mathrm{~A}$ & $2.42 \mathrm{~A}$ & $1.04 \mathrm{~A}$ & $15.3 \mathrm{~A}$ & $80 \mathrm{~A}$ & $1.25 \mathrm{~A}$ \\
\hline Oeiras & --- & $4.99 \mathrm{~A}$ & $0.09 \mathrm{~A}$ & $2.20 \mathrm{~A}$ & $0.85 \mathrm{~A}$ & $6.7 \mathrm{~A}$ & $82 \mathrm{~A}$ & $1.27 \mathrm{~A}$ \\
\hline Tupi & --- & $5.04 \mathrm{~A}$ & $0.10 \mathrm{~A}$ & $2.14 \mathrm{~A}$ & $1.04 \mathrm{~A}$ & $14.3 \mathrm{~A}$ & $81 \mathrm{~A}$ & $1.22 \mathrm{~A}$ \\
\hline Icatu & --- & $5.03 \mathrm{~A}$ & $0.06 \mathrm{~A}$ & $2.31 \mathrm{~A}$ & $1.07 \mathrm{~A}$ & $7.5 \mathrm{~A}$ & $72 \mathrm{~A}$ & $1.29 \mathrm{~A}$ \\
\hline Obatã & --- & $4.86 \mathrm{~A}$ & $0.10 \mathrm{~A}$ & $1.98 \mathrm{~A}$ & $0.96 \mathrm{~A}$ & $9.5 \mathrm{~A}$ & $89 \mathrm{~A}$ & $1.24 \mathrm{~A}$ \\
\hline Catuaí Vermelho & --- & $4.96 \mathrm{~A}$ & $0.07 \mathrm{~A}$ & $2.08 \mathrm{~A}$ & $0.91 \mathrm{~A}$ & $5.9 \mathrm{~A}$ & $84 \mathrm{~A}$ & $1.23 \mathrm{~A}$ \\
\hline \multirow[t]{2}{*}{ Mean for all cultivars } & With & $4.96 \mathrm{a}$ & $0.10 \mathrm{a}$ & $2.20 \mathrm{a}$ & $0.99 \mathrm{a}$ & $11.7 \mathrm{a}$ & $86 \mathrm{a}$ & $1.29 \mathrm{a}$ \\
\hline & Without & $5.04 \mathrm{a}$ & $0.08 \mathrm{a}$ & $2.18 \mathrm{a}$ & $0.96 \mathrm{a}$ & $8.0 \mathrm{a}$ & $76 \mathrm{a}$ & $1.21 \mathrm{~b}$ \\
\hline C.V. (\%) & & 6.5 & 144.0 & 24.1 & 33.0 & 160.0 & 40.2 & 12.0 \\
\hline
\end{tabular}

${ }^{1 /}$ Means followed by different upper case (cultivar) and lower case letters (green manure) are different by Tukey test at 5\%.

$\mathrm{pH}$ as well as soil $\mathrm{Al}, \mathrm{P}, \mathrm{K}, \mathrm{Ca}$, and $\mathrm{Mg}$ contents (Table 6). On the other hand, an increase in organic carbon content was observed when growing the legume (Table 6), probably due to the high amount of plant biomass produced by the green manure, and to its decomposition. Considering the short time period during which the experiment was carried out, this result indicates that the continued cultivation of the area with green manure of different rooting abilities and plant biomass yield could generate progressive increases in soil humus content as well as in nutrient contents, since organic matter is an important source of macro and micronutrients for soils (Gliessman, 2000).

\section{CONCLUSIONS}

Sunn hemp cropping in association with coffee provided an input of $16 \mathrm{t} \mathrm{ha}^{-1}$ dry matter and the cycling of 444, 21, 241, 191, and $44 \mathrm{~kg} \mathrm{ha}^{-1} \mathrm{~N}, \mathrm{P}, \mathrm{K}, \mathrm{Ca}$, and Mg, respectively.

The biological fixation of $\mathrm{N}$ provided an $\mathrm{N}$ input higher than $200 \mathrm{~kg} \mathrm{ha}^{-1}$ of $\mathrm{N}$, demonstrating that fertilizing organic systems with $\mathrm{N}$ constitutes an alternative for the producer.

Sunn hemp cropping resulting in an accumulated $\mathrm{N}$ content in the leaf tissue of coffee plants to remain constant after one cropping cycle, contrary to what was observed in the absence of the legume.

Cultivars 'Obatã' and 'Catuaí Vermelho' presented the highest growth rates in height, while cultivars 'Icatu' and 'Oeiras' the lowest rates.

\section{ACKNOWLEDGEMENTS}

To Consórcio Brasileiro de Pesquisa e Desenvolvimento do Café for financing the project. Also to Ernani Corrêa de Meirelles for field work support.

\section{REFERENCES}

ALVAREZ, V.H.V.; RIBEIRO, A.C. Calagem. In: RIBEIRO, A.C.; GONTIJO, P.T.G.; ALVAREZ, V.V.H. (Ed.). Recomendações para o uso de corretivos e fertilizantes em Minas Gerais $-5^{\text {a }}$ aproximação. Viçosa: Comissão de Fertilidade do Solo do Estado de Minas Gerais, 1999. p.43-60.

ALVES, B.J.R.; BAÊTA, A.M.; ALVES, J.V. Protocolo da Embrapa Agrobiologia para Análise de Nitrogênio em Adubos Orgânicos, Solo e Tecidos. Seropédica: Embrapa Agrobiologia, 1999. 17p. (Documentos, $100)$.

ASOCIACION NACIONAL DEL CAFÉ - ANACAFÉ. Manual de caficultura orgánica. Guatemala, 1999. 159p.

BATAGLIA, O.C.; FURLANI, A.M.C; TEIXEIRA, J.P.F.; FURLANI, P.R.; GALLO, J.R. Métodos de análise química de plantas. Campinas: Instituto Agronômico, 1983. 48p. (Boletim Técnico, 78).

BODDEY, R.M.; PEOPLES, M.B.; PALMER, B.; DART, P.J. Use o the ${ }^{15} \mathrm{~N}$ natural abundance technique to quantify biological nitrogen fixation by woody perennials. Nutrient Cycling in Agroecosystems, v.57, p.235270, 2000.

CALEGARI, A.; MONDARDO, A.; BULISANI, E.A.; WILDNER, L. do P.; COSTA, M.B.B. da; ALCÂNTARA, P.B.; MIYASAKA, S.; AMADO, T.J.C. Adubação verde no sul do Brasil. 2.ed. Rio de Janeiro: ASPTA, 1993. 346p.

CHAVES, J.C.D. Modelo para utilização de adubos verdes em lavouras cafeeiras. In:

CONGRESSO BRASILEIRO DE PESQUISAS CAFEEIRAS, 25., Franca, 1999. Trabalhos apresentados. Rio de Janeiro: MAA; PROCAFÉ, 1999. p.179-180.

CHAVES, J.C.D. Contribuições adicionais da adubação verde para a lavoura cafeeira. In: SIMPÓSIO DE PESQUISA DOS CAFÉS DO BRASIL, 2., Vitória, 2001. Trabalhos apresentados. Vitória: Consórcio Brasileiro de Pesquisa e Desenvolvimento do Café; MAA; Embrapa; Incaper, 2001. p.2440-2448.

COSTA, R.S.C. da; LEÔNIDAS, F.C.; RODRIGUES, V.G.S.; GARCIA, A. Influência de diferentes coberturas de solo na concentração de nutrientes nas folhas de café conilon em Ouro Preto d'Oeste, Rondônia. In: SIMPÓSIO DE PESQUISA DOS CAFÉS DO BRASIL, 3., Porto Seguro, 2003. Anais... Brasília: Embrapa Café, 2003. p.421-422.

DE-POLLI, H. (Coord.). Manual de adubação para o estado do Rio de Janeiro. Itaguaí: Universidade Rural, 1988. 179p.

EMPRESA BRASILEIRA DE PESQUISA AGROPECUÁRIA. Serviço Nacional de Levantamento e Conservação de Solos. Manual de métodos de análises de solos. Rio de Janeiro: SNLCS, 1979. n.p.

ESPÍNDOLA, J.A.A.; GUERRA, J.G.M.; ALMEIDA, D.L. de. Adubação verde: estratégia para uma agricultura sustentável. Seropédica: EMBRAPA, CNPAB, 1997. (Documentos, 42). 
FERNANDES, M.C.A. Defensivos alternativos: ferramenta para uma agricultura ecológica, não poluente, produtora de alimentos sadios. Rio de Janeiro: CREA-RJ, s.d. 14p.

FUNDAÇÃO CARGILL. Adubação orgânica, adubação verde e rotação de culturas no Estado de São Paulo. 2.ed. Campinas, 1984. 138p.

FRANCO, A.A.; SOUTO, S.M. Contribuição da fixação biológica de $\mathrm{N}_{2}$ na adubação verde. In: FUNDAÇÃO CARGILL. Adubação verde no Brasil. Campinas, 1984. cap.21, p.199-215.

GLIESSMAN, S.R. Agroecologia: processos ecológicos em agricultura sustentável. Porto Alegre: Ed. UFRGS, 2000. 653p.

GUIMARÃES, P.T.G.; NOGUEIRA, F.D.; LIMA, P.C. de; GUIMARÃES, M.J.C.L.; POZZA, A.A.A. Adubação e nutrição do cafeeiro em sistema orgânico de produção. Informe Agropecuário, v.23, p.63-81, 2002.

IMPORTANCIA de la sombra en el cafetal. Agroforesteria en las Américas, v.4, p.25-27, 1997.

KHATOUNIAN, C.AA. A reconstrução ecológica da agricultura. Londrina: IAPAR, 2002. 348p.

MALAVOLTA, E.; VITTI, G.C.; OLIVEIRA, S.A. de. Avaliação do estado nutricional das plantas: princípios e aplicações. Piracicaba: Associação Brasileira para Pesquisa da Potassa e do Fosfato, 1989. 201p.

NEVES, M.C.P.; DE-POLLI, H.; PEIXOTO, R.T. dos G.; ALMEIDA, D.L. de. Por que não utilizar uréia como fonte de $\mathrm{N}$ na agricultura orgânica. Cadernos de Ciência e Tecnologia, v.19, p.313-331, 2002.
PAVAN, M.A.; CHAVES, J.C.D. Importância da matéria orgânica nos sistemas agrícolas. Londrina: IAPAR, 1998. 35p. (Circular Técnica, 98).

RESENDE, A.S. A fixação biológica do nitrogênio (FBN) como suporte da produtividade e fertilidade nitrogenada dos solos na cultura de cana-deaçúcar: uso de adubos verdes. Seropédica: UFRRJ, 2000. 145p. (Tese Livre-Docência).

RiBEIRO, A.C.; GONTiJO, P.T.G.; AlvAREZ V., V.H. (Ed.) Recomendações para o uso de corretivos e fertilizantes em Minas Gerais $-5^{\text {a }}$ aproximação. Viçosa, Comissão de Fertilidade do Solo do Estado de Minas Gerais, 1999. 359p.

RICCI, M. dos S.F.; ARAÚJO, M.C.F.; FRANCH, C.M.C. Cultivo orgânico do café: recomendações técnicas. Brasília: Embrapa Informação Tecnológica, 2002. 101p.

SAGGIN JR., O.J.; SIQUEIRA, J.O. Micorrizas arbusculares em cafeeiro. In: SIQUEIRA, J.O. Avanços em fundamentos e aplicação de micorrizas. Lavras: UFLA, DCS; DCF, 1996. 290p.

SHEARER, G.; KOHL, D.H. N2-fixation in field settings: estimations based on natural ${ }^{15} \mathrm{~N}$ abundance. Australian Journal of Plant Physiology, v.13, p.699-756, 1986.

Received August 08, 2004

Accepted January 24, 2005 